\title{
PENGENALAN ETNOBOTANI PEMANFAATAN TANAMAN SEBAGAI OBAT KEPADA MASYARAKAT DESA CABAK JIKEN KABUPATEN BLORA
}

\author{
Setyo Eko Atmojo \\ FKIP Universitas PGRI Yogyakarta \\ SetyoAtmojo@yahoo.co.id
}

\section{Pendahuluan}

Pertumbuhan ekonomi indonesia yang di klaim oleh pemerintah lebih dari $6 \%$ ternyata belum diraskan sepenuhnya oleh masyarakat. Kondisi ekonomi di masyarakat pedesaan saat ini masih belum tampak terjadi perubahan yang signifikan jika dibandingkan perhitungan ekonomi pemerintah. Setidaknya itulah gambaran yang terjadi pada masyarakat di desa Cabak kecamatan Jiken Kabupaten Blora. Masyarakat yang hidup di sekitar hutan yang saat ini dijadikan kawasan cagar alam Cabak oleh pemerintah kabupaten Blora. Hutan di kawasan Cabak ini memiliki mayoritas tanaman jati (Tectona grandis). Selain tanaman utama jati didalam hutan juga terdapat berbagai tanaman yang berpotensi untuk digunakan sebagai obat herbal. Selama ini masyarakat desa Cabak hanya memanfaatkan tanaman yang ada di dalam hutan untuk pakan ternak, bahan sayuran, dan kayu bakar dari ranting ranting pohon yang sudah mengering.

Pengetahuan masyarakat tentang pemanfaatan tanaman sebagai obat hanya sampai pada sebatas pemanfaatan temu lawak untuk menambah nafsu makan. Selain pengetahuan yang dimiliki masyarakat saat ini hanya sebatas pengetahuan turun temurun sebagai bentuk interaksi antara masyarakat dengan lingkungannya khususnya tumbuhan (etnobotani). Di negara Indonesia, sekalipun pelayanan kesehatan telah berkembang, jumlah masyarakat yang memanfaatkan pengobatan tradisional tetap tinggi. Menurut Survei Sosial Ekonomi Nasional tahun $2001,57,7 \%$ penduduk Indonesia melakukan pengobatan sendiri tanpa bantuan medis dengan memilih cara pengobatan tradisional lainnya tidak terkecuali masyarakat di desa Cabak. Akan tetapi pemanfaatan tumbuhan sebagai obat pada masyarakat di desa Cabak masih rendah sehingga perlu di lakukan pengenalan terhadap masyarakat tentang etnobotani pemanfaatan tumbuhan sebagai obat.

Masyarakat masih sulit mengakses fasilitas kesehatan semacam puskesmas apalagi rumah sakit. Ditambah dengan harga obat sintetis yang mahal dan efek sampingnya bagi kesehatan meningkatkan kembali pengetahuan masyarakat tentang penggunaaan obat tradisional oleh masyarakat dengan memanfaatkan sumberdaya alam yang ada di sekitar perlu untuk dilakukan. Sebagai langkah awal yang sangat membantu untuk mengetahui suatu 
tumbuhan berkhasiat obat adalah dari pengetahuan masyarakat tradisional secara turun temurun (Dharma, 2001). Menurut Rifai (1998), kelompok etnik tradisional di Indonesia mempunyai ciri-ciri dan jati diri budaya yang sudah jelas terdefinisi, sehingga diduga kemungkinan besar persepsi dan konsepsi masyarakat terhadap sumberdaya nabati di lingkungannya berbeda, termasuk dalam pemanfaatan tumbuhan sebagai obat tradisional. Sudah ada penelitian tentang jenis-jenis tumbuhan yang berpotensi dan diduga berpotensi sebagai obat. Penelitian tentang pengetahuan dan pemanfaatan tumbuhan obat oleh masyarakat lokal telah banyak dilakukan di Indonesia, di antaranya pemanfaatan suku Zingiberaceae sebagai obat tradisional oleh masyarakat Lembak Delapan, Bengkulu (Siagian $\&$ Sunaryo, 1996). Selain itu, penelitian tentang inventarisasi tumbuhan obat tradisional dan pemanfaatannya telah dilakukan oleh Des (1993) di kotamadya Padang.

Untuk itu perlu dilakukan pemberian informasi tentang pemanfaatan suku tanaman yang berpotensi sebagai bahan obat tradisional berdasarkan kajian etnobotani. Tujuan dilakukannya pengenalan etnobotani kepada masyarakat adalah untuk meningkatkan pengetahuan masyarakat tentang tanaman yang dapat dimanfaatkan sebagai obat, sehingga dapat meningkatkan kesehatan masyarakat dan kesejahteraan masyarakat jika produk obat dari tanaman ini dapat diproduksi dan dikemas secara baik untuk dijual.

\section{Pembahasan}

Etnobotani berasal dari kata etno (etnis) dan botani. Etno berarti masyarakat adat/kelompok sosial kebudayaan yang mempunyai arti tertentu karena keturunan, adat, agama, bahasa dan lain sebagainya. Sedangkan botani adalah tumbuh tumbuhan. Etnobotani adalah interaksi antara masyarakat setempat dengan lingkungan hidupnya, secara spesifik pada tumbuh tumbuhan serta pengkajian penggunaan tumbuhan sebagai makanan, perlindungan atau rumah, pengobatan, pakaian, perburuan dan upacara adat. Suatu bidang ilmu yang mempelajari hubungan antara masyarakat lokal dan alam lingkungannya meliputi sistem pengetahuan tentang sumber daya tumbuhan (Purwanto, 1999). Dalam rangka memberikan pengetahuan yang lebih baik kepada masyarakat tentang pemanfaaatan tumbuhan sebagai obat maka perlu diperkenalkan etnobotani tumbuhan yang berpotensi sebagai obat kepada masyarakat.

Sebelum memperkenalkan jenis tumbuhan yang dapat digunakan sebagai obat perlu diberikan penjelasan mengenai penyakit kepada masyarakat. Kepercayaan yang berkembang di masyarakat membagi penyakit menjadi tiga jenis, yaitu penyakit biasa, penyakit karena magis dan penyakit karena makanan. Penyakit biasa adalah penyakit yang umum diderita oleh penduduk seperti demam, batuk, sakit badan dan sakit kepala yang timbul akibat 
perubahan cuaca atau kuman penyakit. Penyakit karena magis diyakini oleh penduduk timbul akibat pelanggaran tata cara hidup di alam seperti halnya penyakit gila, ayan atau lumpuh. Menurut mereka terdapat tiga bentuk pengobatan yang digunakan oleh penduduk untuk mengobati penyakit yaitu tatangkalan atau pengobatan dengan tumbuhan, obat warung, dan jampe. Untuk mengobati penyakit biasa, sebagian penduduk masih menggunakan tumbuhan obat walaupun sebagian sudah beralih pada penggunaan obat warung. Namun demikian penduduk masih mengetahui berbagai macam tumbuhan untuk pengobatan. Pengetahuan masyarakat tentang pemanfaatan tumbuhan sebagai obat perlu diperbaiki dengan menggunakan penjelasan yang lebih rasional dan ilmiah. Kerangka berpikir yang dapat dikembangkan dalam pengenalan etnobotani tanaman obat terhadap masyarakat dapat dilihat pada Gambar 1.

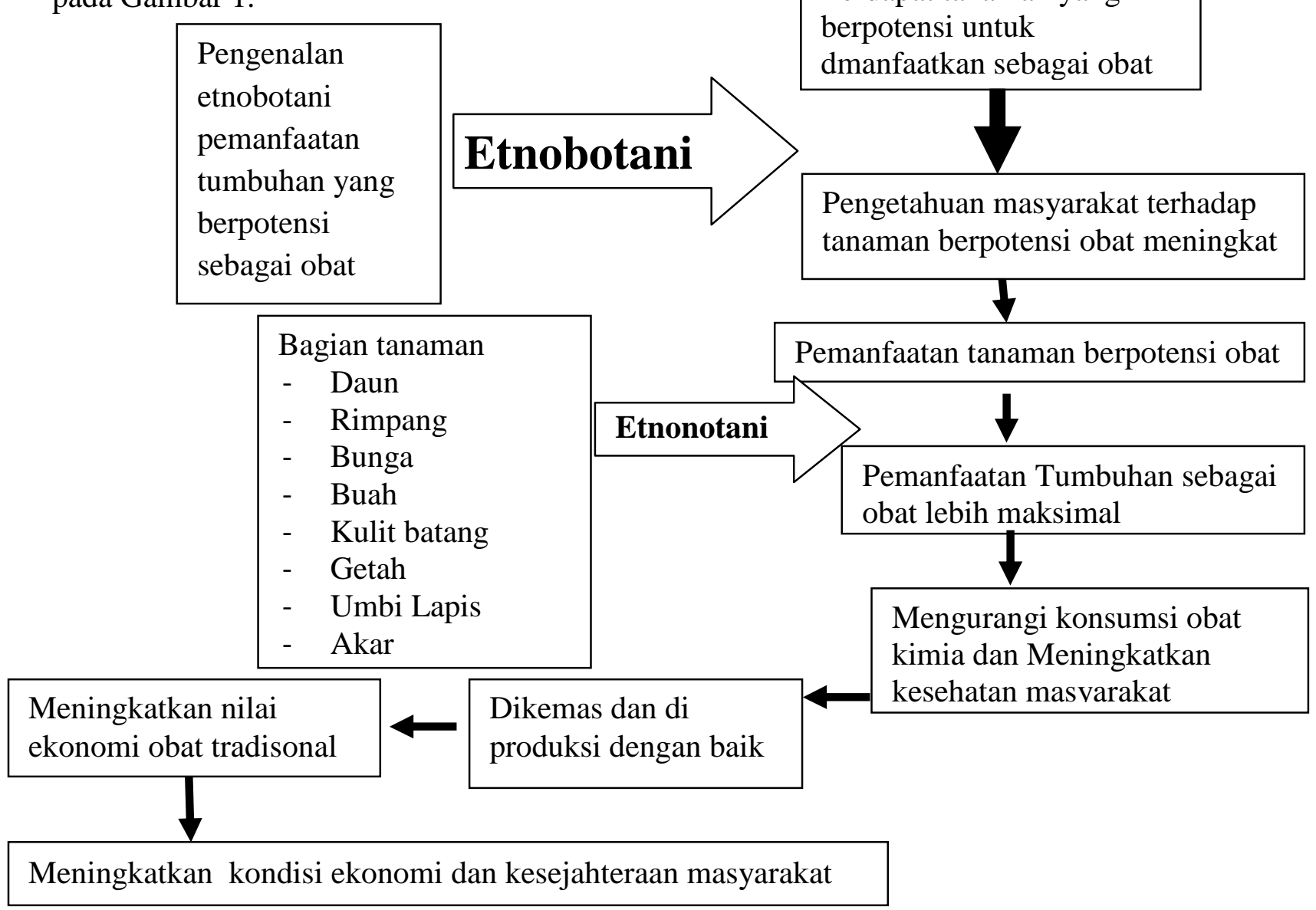

Gambar 1. Diagram Pengenalan Etnobotani Tanaman Obat Terhadap Masyarakat

Berdasarkan Gambar 1 dapat dilihat bahwa pengenalan etnobotani pemanfaatan tanaman yang berpotensi sebagai obat dapat memberikan perubahan tentang pengetahuan awal masyarakat tentang berbagai jenis tanaman yang dapat dimanfaatkan sebagai obat. Berawal dari peningkatan pengetahuan masyarakat terhadap tanaman yang berpotensi sebagai obat selanjutnya masyarakat yang selama ini hanya mengenal bagian bagian tertentu dari 
suatu tanaman yang dapat dimanfaatkan sebagai obat akan memperoleh tambahan pengetahuan mengenai berbagai bagian tumbuhan lain yang ternyata masih dapat digunakan sebagai obat. Penjelasan etnobotani yang diberikan kepada masyarakat meliputi penjelasan tentang pemanfaatan jenis tumbuhan yang dapat digunakan sebagai bahan obat-obatan tradisional antara lain meliputi berbagai Genus, Famili, Ordo, Kelas, dan Divisi. Dari berbagai jenis tumbuhan obat tersebut, jenis tumbuhan dari Famili Zingiberaceae (temutemuan) adalah yang paling mudah untuk diperoleh dan dimanfaatkan oleh masyarakat. Jenis tumbuhan lain yang juga dapat digunakan adalah bawang merah (Allium cepa var ascalonicum), sedangkan bagian yang paling dapat banyak digunakan sebagai obat oleh masyarakat adalah daun.

Dalam mengobati suatu jenis penyakit dapat digunakan lebih dari satu jenis tumbuhan yang berupa ramuan obat seperti jamu, param, semar, dikunyah dikumur dan sebagainya. Penjelasan tentang penggunaan obat terutama untuk mengobati suatu penyakit seperti batuk, sakit kulit, sakit perut, rematik, sesak napas, demam dan sakit kepala. Pemanfaatan obat tradisonal dapat menjadi pilihan utama masyarakat karena akses fasilitas kesehatan yang jauh dan harga obat sintesis yang mahal. Sebagian masyarakat dapat menggunakan tanaman obat karena tanaman tersebut memiliki khasiat khasiat tertentu. Salah satu tumbuhan yang dapat digunakan adalah kencur. Seperti yang diketahui khasiat kencur bersama dengan bahan lain dalam ramuan dapat digunakan sebagai obat desentri, maag, peluruh keringat, pencahar, campuran obat sariawan, bengkak, radang lambung, urat tegang dan batuk kering pada anakanak Hariyadi (2001).

Selain kencur tanaman lain yang dapat dimanfaatkan adalah jahe. Rimpang jahe mengandung zat kimia yang umumnya digunakan sebagai obat beberapa penyakit atau kelemahan jasmani, misalnya untuk obat demam, batuk dan sakit perut. Jahe mengandung zat-zat yang dapat menyembuhkan penyakit seperti limonene sebagai obat flu, 1,8 cineole sebagai perangsang keluarnya keringat, obat demam, pusing dan masuk angin, serta guanicol untuk meredakan batuk (Tim Lentera, 2004). Selain itu jahe juga dapat digunakan sebagai obat reumatik dengan cara dioleskan sebagai obat gosok, obat pegal-pegal dengan dibuat parem, sebagai kompres di dahi pada sakit kepala, obat batuk, mencret dan muntah-muntah dibuat dengan dicampur bahan-bahan lain sebagai obat gosok (Thomas, 1992). Jahe dimanfaatkan untuk pengobatan reumatik, batuk kering, kolera, difteri dan radang tenggorokan (Hariyadi, 2001) dan (Hidayat,2001). Beberapa jenis tumbuhan yang memiliki potensi untuk digunakan sebagai obat dapat dilihat pada Tabel 1. 
Tabel 1. Contoh Jenis Tumbuhan Dan Potensinya Sebagai Obat

\begin{tabular}{|c|c|c|c|c|c|c|}
\hline No. & $\begin{array}{l}\text { Nama } \\
\text { Lokal }\end{array}$ & $\begin{array}{l}\text { Nama } \\
\text { Umum }\end{array}$ & Nama Ilmiah & $\begin{array}{c}\text { Simplisia } \\
\text { Obat }\end{array}$ & $\begin{array}{c}\text { Kandungan } \\
\text { Senyawa } \\
\text { Kimia* }\end{array}$ & $\begin{array}{c}\text { Khasiat } \\
\text { Sebagai } \\
\text { Obat }\end{array}$ \\
\hline 1. & Jahe & Jahe & $\begin{array}{l}\text { Zingiber } \\
\text { officinale }\end{array}$ & Rimpang & $\begin{array}{l}\text { Minyak atsiri, } \\
\text { zingeton, } \\
\text { Zingibetol, } \\
\text { zingiberin, } \\
\text { borneol dan } \\
\text { sineol. }\end{array}$ & $\begin{array}{ll}\text { Batuk } & \text { dan } \\
\text { rematik } & \end{array}$ \\
\hline 2. & Kunyit & Kunyit & Curcuma & Rimpang & $\begin{array}{l}\text { Minyak atsiri, } \\
\text { kurkuminoid } \\
\text { dan kurkumin }\end{array}$ & $\begin{array}{l}\text { Batuk, } \\
\text { mata, } \\
\text { ambeien, } \\
\text { kepala, } \\
\text { pinggang, } \\
\text { bisul dan } \\
\text { diare } \\
\end{array}$ \\
\hline 3. & Temu ireng & Temu hitam & $\begin{array}{l}\text { Curcuma } \\
\text { aeruginosa }\end{array}$ & Rimpang & $\begin{array}{l}\text { Minyak atsiri, } \\
\text { zat pati dan zat } \\
\text { lemak }\end{array}$ & $\begin{array}{l}\text { Gatal-gatal } \\
\text { pada kulit }\end{array}$ \\
\hline 4. & Kencur & Kencur & $\begin{array}{l}\text { Kaemfperia } \\
\text { galanga }\end{array}$ & Rimpang & $\begin{array}{|lr|}\text { Minyak } & \text { atsiri, } \\
\text { borneol, } & \\
\text { kamfer, } & \text { sineol } \\
\text { dan } & \text { etil } \\
\text { alkohol } & \\
\end{array}$ & $\begin{array}{l}\text { Kepala, } \\
\text { dingin, } \\
\text { batuk, mata } \\
\text { dan rematik }\end{array}$ \\
\hline 5. & Laos & Lengkuas & Alpinia galanga & Rimpang & $\begin{array}{l}\text { Minyak } \\
\text { eugenol, } \\
\text { quiterpen, } \\
\text { galangol, }\end{array}$ & $\begin{array}{l}\text { Gata-gatal, } \\
\text { pegal linu, } \\
\text { lesu, bisul, } \\
\text { panas, }\end{array}$ \\
\hline 6. & Jarak duri & Jarak kepyar & $\begin{array}{l}\text { Ricinus } \\
\text { communis }\end{array}$ & $\begin{array}{l}\text { Daun, akar } \\
\text { dan biji } \\
\\
\end{array}$ & $\begin{array}{l}\text { Minyak ricinic, } \\
\text { asam ricinic, } \\
\text { asam } \\
\text { isoricinolie } \\
\text { dan asam oliec } \\
\end{array}$ & $\begin{array}{l}\text { Kulit, } \\
\text { rematik dan } \\
\text { luka bakar }\end{array}$ \\
\hline 7. & Jarak & Jarak pagar & Jatropha curcas & $\begin{array}{l}\text { Daun } \\
\text { getah }\end{array}$ & \begin{tabular}{|l|} 
Alkaloid, \\
amalinin, \\
serpentin, \\
minyak
\end{tabular} & $\begin{array}{l}\text { Panas, } \\
\text { sariawan } \\
\text { dan } \\
\text { bakar }\end{array}$ \\
\hline 8. & Kemiri & Kemiri & Aleurites & $\begin{array}{l}\text { Buah } \\
\text { daun }\end{array}$ & Minyak lemak & $\begin{array}{ll}\text { Batuk dan } \\
\text { koreng }\end{array}$ \\
\hline 9. & Kayu manis & Daun katuk & $\begin{array}{l}\text { Saurophus } \\
\text { androgyrus }\end{array}$ & Daun & $\begin{array}{l}\text { Protein, } \\
\text { kalsium, } \\
\text { posfor, zat besi } \\
\text { dan vitamin } \\
\end{array}$ & $\begin{array}{l}\text { Panas } \\
\text { dalam }\end{array}$ \\
\hline
\end{tabular}




\begin{tabular}{|c|c|c|c|c|c|c|}
\hline 10 & Telo & $\begin{array}{l}\text { Ketela } \\
\text { pohon }\end{array}$ & $\begin{array}{l}\text { Manihot } \\
\text { utilisima }\end{array}$ & $\begin{array}{l}\text { Umbi } \\
\text { dan daun }\end{array}$ & $\begin{array}{l}\text { akar } \begin{array}{l}\text { Bioalkali, } \\
\text { asam sianida } \\
\text { dan linamarine }\end{array}\end{array}$ & Bisul \\
\hline 11. & Kamboja & Kamboja & Plumeria & $\begin{array}{l}\text { Kulit batang } \\
\text { dan getah }\end{array}$ & $\begin{array}{l}\text { Alakloid } \\
\text { plumerin, } \\
\text { fernozol, } \\
\text { plumoplumerin }\end{array}$ & $\begin{array}{l}\text { Panas, luka } \\
\text { dan gigi }\end{array}$ \\
\hline 12. & Jambe & Pinang & Pinanga kulii & buah & $\begin{array}{l}\text { Gurasin } \\
\text { areoalidin }\end{array}$ & $\begin{array}{ll}\text { Batuk dan } \\
\text { patah } \\
\text { tulang } \\
\end{array}$ \\
\hline 13. & Kelopo & Kelapa & Cocos nucifera & $\begin{array}{l}\text { Daging } \\
\text { buah }\end{array}$ & $\begin{array}{l}\text { Minyak, } \\
\text { danlemak, }\end{array}$ & $\begin{array}{l}\text { Jantung, } \\
\text { gigit }\end{array}$ \\
\hline
\end{tabular}

*)Kajian Pustaka

Tabel Dimodifikasi dari Sang Ketut Sudirga

\section{Kesimpulan}

Pengenalan etnobotani kepada masyarakat dapat meningkatkan pengetahuan masyarakat tentang pemanfaatan tumbuhan yang berpotensi sebagai obat secara maksimal. Pemanfaatan tumbuhan sebagai obat secara maksimal dapat meningkatkan kesehatan dan ekonomi masyarakat jika produk hasil olahan obat dapat diproduksi dengan baik dan dikemas menarik.

\section{Daftar Pustaka}

Des. M. 1993. Inventarisasi Tumbuhan Obat Tradisional di Kotamadya Padang. Abstr.2678. hal 38. Dalam Sari Laporan Penelitian dan Survei Jilid 18. 1995. Pusat Dokumentasi dan Informasi Ilmiah - LIPI, Jakarta.

Dharma, A. 2001.Uji Bioaktifitas Metabolit Sekunder. Makalah Workshop Peningkatan Sumber Daya Alam Hayati dan Rekayasa Bioteknologi. FMIPA UNAND, Padang.

Hariyadi, S. 2001. Khasiat Tanaman TOGA untuk Pengobatan Alternatif. Penerbit Kalamedia, Jakarta.

Hidayat, S. 2001. Ke Alam Mencati Obat Batuk \& Flu. Intisari no. 453-TH XXXVII. April 2001. Hal 58-63.

Purwanto Y., 1999. Peran dan Peluang Etnobotani Masa kini di Indonesia Dalam Menunjang Upaya Konservasi dan Pengembangan Keanekaragaman Hayati.Prosiding Seminar Hasil-hasil Penelitian Bidang Ilmu Hayat. Pusat Antar Universitas Ilmu Hayat IPB, Bogor.

Rifai, M.A. 1998. Pemasakinian Etnobotani Indonesia : Suatu Keharusan demi Peningkatan Upaya Pemanfaatan, Pengembangan dan Penguasaannya. Prosiding Seminar Nasional Etnobotani III ( 5-6 Mei 1998, Denpasar-Bali) : 352-356.

Sang Ketut Sudirga. Jurusan Biologi Fakultas MIPA. Universitas Udayana E; jurnal;bumilestari/rtf;sangket.doc /12. 7-12.

Siagian, M.H \& Sunaryo. 1996. Pemanfaatan Suku Zingiberaceae Sebagai Obat Tradisional oleh Masyarakat Lembak Delapan, Bengkulu, Abstr. 0554. Hlm 246 Dalam Indeks BeranotasiKeanekaragaman Hayati dalam Publikasi Ilmiah Staf Peneliti Pusat PenelitianBiologi-LIPI, 2002. Biodiversity Conservation Project, Pusat Penelitian Biologi-LIPI, Bogor.

Thomas, A.N.S. 1992 Tanaman Obat Tradisional 2. Kanisius, Yogyakarta

Tim Lentera. 2004. Khasiat \& Manfaat Jahe si Rimpang Ajaib. AgroMedia Pustaka, Jakarta 